\title{
Production of Poly (3-hydroxybutyrate) from cassava starch hydrolysate by Pseudomonas aeruginosa NCIB 950
}

\author{
Aremu, M.O. ${ }^{1^{*}}$, Layokun, S.K. ${ }^{2}$ and Solomon, B.O. ${ }^{3}$ \\ $1^{*}$ Department of Chemical Engineering, Ladoke Akintola University of Technology, \\ Ogbomoso, Nigeria \\ 2 Department of Chemical Engineering, Obafemi Awolowo University, lle-Ife, Nigeria. \\ ${ }^{3}$ National Biotechnology Development Agency (NABDA), Abuja, Nigeria. \\ ${ }^{1 *}$ Correspondence Author: debola_4@yahoo.co.uk
}

\begin{abstract}
The biosynthesis of polyhydroxybutyrate by Pseudomonas aeruginosa grown on reducing sugar hydrolysate obtained from raw cassava starch as the sole carbon source and di-ammonium sulphate as the limiting nutrient was investigated. This involved hydrolysis of extracted starch from freshly harvested cassava tubers using enzyme-enzyme method of hydrolysis, followed by aerobic fermentation of Pseudomonas aeruginosa on a mixture of the hydrolysate and nutrient media in batch cultures. The biomass growth was measured by cell dry weight and the polyhydroxybutyrate content measured by gas chromatography. The results obtained show that the hydrolysate supported the growth of the organism and when the fermentation was shutdown after $84 \mathrm{~h}$, a biomass yield on substrate $\left(Y_{x / s}\right)$ of $0.186 \mathrm{~g} \mathrm{~g}^{-1}$ was obtained with corresponding product yield on substrate $\left(Y_{p / s}\right)$ of $0.106 \mathrm{~g} \mathrm{~g} \mathrm{~g}^{-1}$. The results also show that the organism accumulated polyhydroxybutyrate in excess of $50 \%$ of the cell dry weight by giving a final polyhydroxybutyrate yield on biomass $\left(\mathrm{Y}_{\mathrm{p} / \mathrm{x}}\right)$ of $0.577 \mathrm{~g} \mathrm{~g}^{-1}$ which agrees with the general trend in polyhydroxybutyrate production.
\end{abstract}

Keywords: Polyhydroxybutyrate, Pseudomonas aeruginosa, biosynthesis, hydrolysate biomass yield and analysis.

\section{INTRODUCTION}

Global focus is gradually turning away from synthetic polymers as a major source of raw material to polyhydroxybutyrate (a biodegradable polymer) for plastic and polymeric materials due to its biodegradability, environmental friendliness and ease of production from renewable resources. Poly (3hydroxybutyrate) is a biodegradable polymer belonging to a group of bacteria synthesized polymer collectively called polyhydroxyalkanoates that accumulates in some microorganisms under unbalanced growth conditions (Anderson and Dawes, 1990). When nutrient supplies such as nitrogen, oxygen, phosphorus, sulphur or magnesium are imbalanced, it is advantageous for bacteria to store excess carbon by polymerizing soluble carbon intermediates into water-insoluble molecules like polyhydroxyalkanoates inside their cells (Madison and Huisman, 1999). Polyhydroxybutyrate is a polymer with many desirable properties because it is biodegradable and also immunologically compatible with human tissue (Lafferty et al., 1988). Alcaligenes eutrophus is currently used for commercial polyhydroxybutyrate production, but many other microorganisms also accumulate polyhydroxybutyrate and can grow on more different carbon sources than Alcaligenes eutophus. (Page,1992). The extensive usage of petrochemical polymers due to their versatile properties especially durability is causing severe problem in waste management thereby affecting the aesthetic quality of cities, water bodies and natural areas (Full et al., 2006). Also, the increased costs of solid waste disposal as well as the potential hazards from synthetic polymer waste incineration, such as dioxin emission from poly-vinyl chloride (PVC) incineration has made synthetic polymer source of waste a management problems. As a result, lot of research is now focused on the production of biodegradable polymers such as polyhydroxybutyrate being environmental friendly. The production cost of commercially available polyhydroxyalkanoates is comparatively higher than that of conventional 
synthetic polymers (Van-Thuoc et al., 2008). This high cost of polymer production is the major bottleneck in the commercialization of biodegradable plastics.

However, process economics reveal that the use of inexpensive and renewable carbon substrates such as agro industrial wastes and by-products as feedstock can contribute to as much as $40-50 \%$ reduction in the overall production cost (Choi and Lee, 1999; Kim, 2000). For this work, the main carbon source is reducing sugar obtained from hydrolysed cassava starch. Cassava (Manihot esculenta) is a slightly woody, generally shrubby plant that typically grows from one to three meters (310 feet) in height (Katz and Weaver, 2003). The leaves are nearly palmate (fan- or hand-shaped) and dark green in color. It tolerates drought better than most other crops, and can grow well in very poor, acidic soils through its symbiotic relationship with soil fungi (mycorrhizae) (Katz and Weaver, 2003). Cassava is a prolific crop, which can yield up to $13 \mathrm{M}$ tonnes /acre (Bender and Bender, 2005). The roots are very rich in starch and are harvestable after six to twelve months and can be harvested any time in the following two years thus providing farmers with a remarkable amount of flexibility (Katz and Weaver, 2003).

\section{MATERIALS AND METHODS}

Microorganism: Pseudomonas aeruginosa NCIB 950 strain used for this study was collected from the stock culture of the Department of Microbiology, Obafemi Awolowo University, Ile-Ife, Nigeria. The microorganism was grown on nutrient agar slant containing yeast extract, beef extract, peptone and $\left(\mathrm{NH}_{4}\right)_{2} \mathrm{SO}_{4}$ at $30{ }^{\circ} \mathrm{C}$ for $3-4$ days and then stored at 4 ${ }^{\circ} \mathrm{C}$ with regular sub-culturing.

Preparation of substrate solution: Raw cassava starch (obtained from cassava tubers, freshly harvested from a farm in Ile-Ife, Nigeria) was made into slurry by dissolving in appropriate quantity of distilled water containing $40 \mathrm{ppm} \mathrm{Ca}{ }^{2+}$ to form $25 \%$ starch slurry. This starch slurry was gelatinised at $105{ }^{\circ} \mathrm{C}$ for $10 \mathrm{~min}$. The gelatinised starch was liquefied at a lower temperature of $95{ }^{\circ} \mathrm{C}$ and $\mathrm{pH}$ of 6.5 by adding $\alpha-$ amylase ( $5 \mathrm{ml}$ enzyme $\mathrm{kg}^{-1}$ of Novo Termamyl obtained from Bacillus licheniformis) with continuous stirring for $2 \mathrm{~h}$. The liquefied starch was saccharified at a pH of 4.5 and $60{ }^{\circ} \mathrm{C}$ for $72 \mathrm{~h}$ by adding Novo amyloglucosidase (AMG) obtained from Aspergillus niger (5 $\mathrm{ml}$ enzyme $\mathrm{kg}^{-1}$ starch), with continuous agitation throughout the period of hydrolysis. After saccharification, the mixture was heated for $15 \mathrm{~min}$ in boiling water to stop the activities of the enzymes and filtered to get the syrup used as substrate for the production of polyhydroxybutyrate.

Mineral salts preparation: The mineral salts was prepared according to the method of Du et al., 2001a such that one litre of solution contained $1.5 \mathrm{~g}$ of $\left(\mathrm{NH}_{4}\right)_{2} \mathrm{SO}_{4}, 5.8 \mathrm{~g}$ of $\mathrm{K}_{2} \mathrm{HPO}_{4}, 3.7 \mathrm{~g}$ of $\mathrm{KH}_{2} \mathrm{PO}_{4}, 0.4 \mathrm{~g}$ of $\mathrm{MgSO}_{4}$ and $1 \mathrm{ml}$ of a microelement solution. The microelement solution was prepared such that one litre of it contained $2.78 \mathrm{~g} \mathrm{FeSO}{ }_{4} .7 \mathrm{H}_{2} \mathrm{O}, 1.98 \mathrm{~g}$ of $\mathrm{MnCl}_{2} .4 \mathrm{H}_{2} \mathrm{O}, \quad 2.81 \mathrm{~g}$ of $\mathrm{CoSO}_{4} .7 \mathrm{H}_{2} \mathrm{O}, 1.67 \mathrm{~g}$ of $\mathrm{CaCl}_{2} .2 \mathrm{H}_{2} \mathrm{O}, 0.17 \mathrm{~g}$ of $\mathrm{CuCl}_{2} \cdot 2 \mathrm{H}_{2} \mathrm{O}$, and $0.29 \mathrm{~g}$ of $\mathrm{ZnSO}_{4}$.

Preparation of inoculums: The inoculums were prepared in eight different $250 \mathrm{ml}$ Erlenmeyer conical flasks containing $80 \mathrm{ml}$ of the reducing sugar hydrolysate and $20 \mathrm{ml}$ of mineral salts medium each. The flasks were cotton plugged and autoclaved at $121{ }^{\circ} \mathrm{C}$ for $15 \mathrm{~min}$. The sterilized medium was allowed to cool to ambient temperature and the microorganism (Pseudomonas aeruginosa) was scraped from the agar slant and added aseptically to each of the medium in the flasks to make $100 \mathrm{ml}$ of the seed medium in each of the flasks. The flasks were transferred to the gyratory incubator shaker (New Brunswick Scientific Co., USA) and growth was achieved at a temperature of $30{ }^{\circ} \mathrm{C}$ and agitation rate of $200 \mathrm{rpm}$ after incubation for $48 \mathrm{~h}$.

Fermentation: The fermentation was carried out aerobically in a bench scale fermentor manufactured by New Brunswick Scientific Co., USA. The fermentor vessel containing $1 \mathrm{~L}$ of the mineral salts solution and 2.4 liters of the substrate solution was sterilized in the autoclave at $121{ }^{\circ} \mathrm{C}$ for $15 \mathrm{~min}$. The solution in the fermentor vessel was allowed to cool and inoculated with an actively growing inoculum of $800 \mathrm{ml}$. The culture was agitated at $400 \mathrm{rpm}$ with an airflow rate of $2 \mathrm{vvm}$ and fermentation was conducted at $30^{\circ} \mathrm{C}$ and $\mathrm{pH}$ of 7.5. Samples were taken at $6 \mathrm{~h}$ intervals. Each of the samples collected was centrifuged and the supernatant analyzed for reducing sugar and nitrogen content. The residue at the bottom was analyzed for biomass and polyhydroxybutyrate concentration.

\section{Sample analysis}

Reducing sugar concentration: The reducing sugar concentration of the fermentation broth was 
estimated by analyzing the glucose in the supernatant using the DNS method of Miller (1959).

Ammonia nitrogen analysis: The free ammonia nitrogen content of the broth was analyzed by using the method of Marchessault (1996).

Turbidity: The turbidity of the culture medium served as a parameter to follow cell growth during fermentation. To do this $5 \mathrm{ml}$ sample were withdrawn every $6 \mathrm{hr}$ interval, diluted and the absorbance read at $600 \mathrm{~nm}$ on the spectrophotometer.

Biomass concentration: To do this, $20 \mathrm{ml}$ sample was withdrawn every $6 \mathrm{~h}$ interval and centrifuged at $10,000 \mathrm{rpm}$ for $10 \mathrm{~min}$. The supernatant was removed and the precipitate re-washed twice by resuspending in an equal amount of distilled water and repeating the centrifugation process. The washed cells was poured on a pre-weighed filter paper and dried to constant weight in an oven at $60{ }^{\circ} \mathrm{C}$, allowed to cool in a dessicator and the final weight recorded. The biomass weight was determined by subtracting the weight of the filter paper from the weight of the filter paper plus the cells (El- Holi and Al- Delaimy, 2003).

Polyhydroxybutyrate (PHB) concentration: Here $100 \mathrm{ml}$ sample was withdrawn every $6 \mathrm{~h}$ interval throughout the period of fermentation and analyzed for polyhydroxybutyrate concentration using the method of Riis and Mai (1988). The polyhydroxybutyrate content of the sample was quantified using an SRI 8610 gas chromatograph. The gas chromatograph was fitted with an automatic injector and a flame ionization detector which was supplied with $500 \mathrm{ml}$ of air, $30 \mathrm{ml}$ of hydrogen and 30 $\mathrm{ml}$ of helium per minute. The injection split ratio was $100: 1$ with a helium flow of $0.9 \mathrm{ml} / \mathrm{min}$ through the $25 \mathrm{~m}$ long HP5 capillary column. The injector port temperature was $120{ }^{\circ} \mathrm{C}$ and increased by $8{ }^{\circ} \mathrm{C}$ per min to a final temperature of $210^{\circ} \mathrm{C}$. Injections of 5 $\mu \mathrm{l}$ were made and the retention times for the methyl ester of 3-hydroxybutyrate and benzoic acid were 4.1 and $7.0 \mathrm{~min}$ respectively.

\section{RESULTS}

The result obtained from the enzyme-enzyme hydrolysis of raw cassava starch show that $25 \%$ starch slurry gave reducing sugar concentration of $20.4 \%$ with starch conversion efficiency of $81.6 \%$. This result agrees with the previously reported works of Gaouar et al., (1997b) and Aransiola et al., (2006) for the enzyme-enzyme hydrolysis of cassava starch to reducing sugar hydrolysate.

The results obtained for the appropriate dilution and mixing of reducing sugar hydrolysate obtained from the enzyme-enzyme hydrolysis with the mineral solution and inoculum for the batch fermentation studies is presented in Table 1 while the results for the cultivation of Pseudomonas aeruginosa on the reducing sugar hydrolysate in the bioreactor are displayed in Fig. 1 and 2.

Table 1: Initial conditions for the batch fermentation of Pseudomonas aeruginosa in a stirred fermentor.

\begin{tabular}{|l|c|c|c|c|c|}
\hline $\begin{array}{l}\text { Fermentation } \\
\text { Mode }\end{array}$ & $\begin{array}{l}\text { Working } \\
\text { Volume(L) }\end{array}$ & $\begin{array}{l}\text { Initial Reducing } \\
\text { Sugar conc.(g/L) }\end{array}$ & $\begin{array}{l}\text { Initial } \\
\text { nitrogen } \\
\text { conc.(mg/L) }\end{array}$ & $\begin{array}{l}\text { Initial } \\
\text { Total } \\
\text { Biomass(g/L) }\end{array}$ & $\begin{array}{l}\text { Initial } \\
\text { PHB } \\
\text { Conc.(g/L) }\end{array}$ \\
\hline Batch & 4.2 & 13.4 & 72.8 & $0.18(+$ _0.02) & 0.00 \\
\hline
\end{tabular}

The reducing sugar hydrolysate after proper dilution gave initial reducing sugar concentration of $13.4 \mathrm{~g} \mathrm{~L}^{-1}$ while the ammonium sulphate provided the medium with free amino nitrogen concentration of $0.073 \mathrm{~g} \mathrm{~L}^{-1}$. The results show that the substrate (reducing sugar) was able to support the growth of the microorganism (Pseudomonas aeruginosa) since the biomass concentration increases throughout the period of fermentation.

In Fig.1, the biomass concentration increased as the reducing sugar consumption by the microorganism increased while Fig. 2 also show that the polyhydroxybutyrate production increased as the biomass concentration increased. The biomass yield on substarte $Y_{(x / s)}$ obtained was $0.186 \mathrm{~g} \mathrm{~g}^{-1}$, while the product yield on substrate $Y_{(\mathrm{p} / \mathrm{s})}$ was $0.107 \mathrm{~g} \mathrm{~g}^{-1}$ and the corresponding product yield on biomass was $Y_{(p / x)}$ $0.577 \mathrm{~g} \mathrm{~g}^{-1}$. 

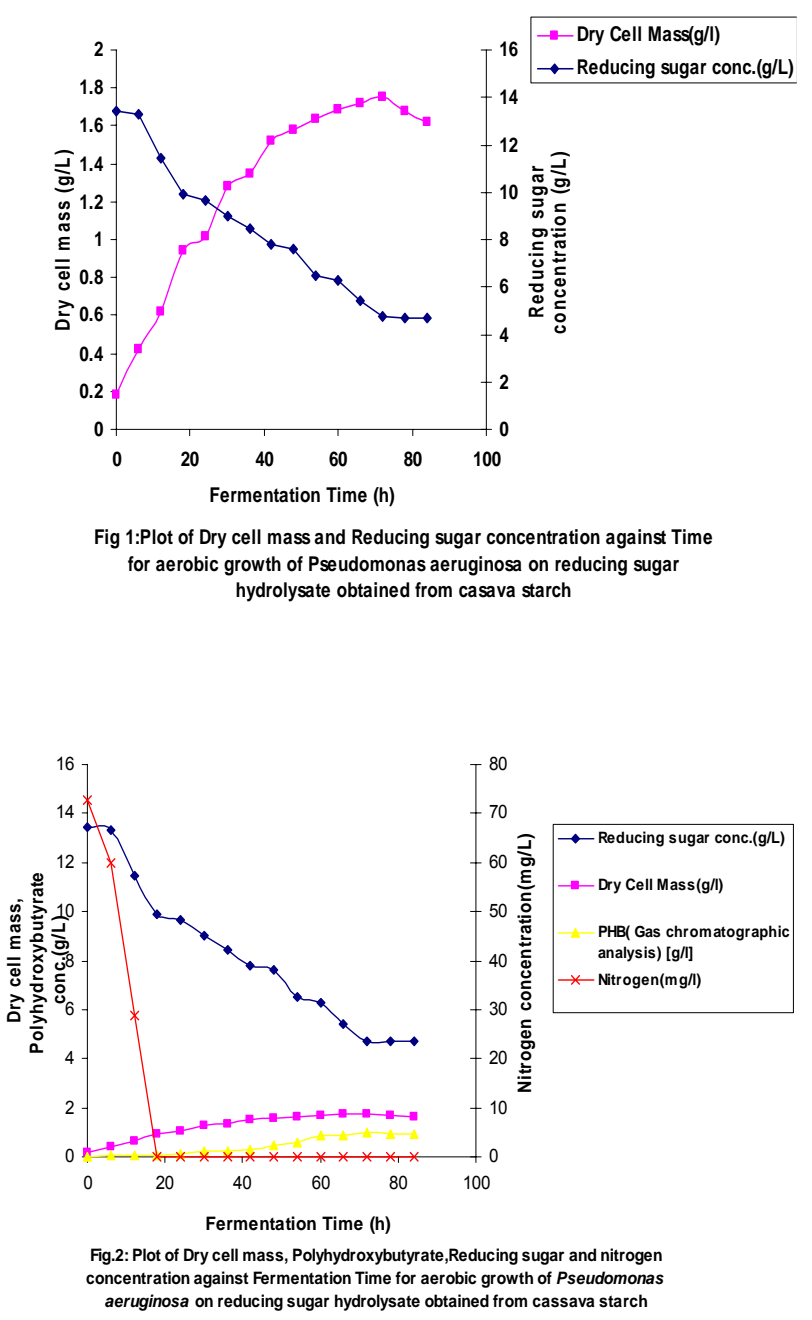

\section{DISCUSSION}

Hydrolysis of raw cassava starch by enzyme has been previously reported (Gaouar et al., 1997b; Omemu et al., 2005; Aransiola et al., 2006). Gaouar et al., (1997b) reported a conversion efficiency of 72 $\%$ for enzymatic hydrolysis of cassava starch to maltose. In the study of Omemu et al., (2005), hydrolysis of raw cassava starch by amylase of Aspergillus niger was reported to give $27.17 \%$ conversion efficiency while Aransiola et al., (2006) reported a conversion efficiency of $87.3 \%$ for the enzyme-enzyme hydrolysis of cassava starch to reducing sugar hydrolysate. Hence, the result of hydrolysis obtained in this study compare favourably with these previously reported works.

Considering the results of fermentation studies, the biomass concentration was observed to increase with time till around $70^{\text {th }} \mathrm{h}$ of fermentation. This can be observed in the curve of biomass growth which is in the exponential phase. After $70^{\text {th }} \mathrm{h}$ of fermentation, the reducing sugar consumption by the microorganism become stagnant which may be due to metabolic activities in the medium, hence, after $70^{\text {th }} \mathrm{h}$, the curve of the biomass growth enters the stationary phase and later started declining.

For polyhydroxybutyrate production, earlier in the fermentation process, there was a little accumulation of polyhydroxybutyrate until after $18^{\text {th }} \mathrm{h}$ of fermentation when the accumulation started appreciating considerably due to the exhaustion of nitrogen in the medium. This observation agrees with the previous works of Brandl et al.(1988); Anderson and Dawes (1990); Rusendi and Sheppard (1996) who all reported that most of the polyhydroxybutyrate accumulation in conventional batch cultures using microorganisms occur after the medium has reached the point of nitrogen limitation. After $18^{\text {th }} \mathrm{h}$, the polyhydroxybutyrate accumulation started appreciating considerably and when the fermentation was shutdown after $84^{\text {th }} \mathrm{h}$, a polyhydroxybutyrate yield of $0.935 \mathrm{~g} \mathrm{~L}^{-1}$ was obtained in a biomass of 1.62 $\mathrm{g} \mathrm{L}^{-1}$ resulting in a polyhydroxybutyrate yield on biomass $Y_{(\mathrm{p} / \mathrm{x})}$ of $0.577 \mathrm{~g} \mathrm{~g}^{-1}$ which translates to 57.7 $\%$ of cell dry weight.

This result compares favourably well with the work of Santimano et al. (2009) using Bacillus sp. strain COL $1 / \mathrm{A} 6$ and reported

(i) $\quad 43.44 \pm 0.25 \%$ PHA of the cell dry weight when grown on commercially available soluble starch

(ii) $\quad 47.5 \pm 1.01 \%$ PHA of the cell dry weight when grown on hydrolysed

citrus pulp waste

(iii) $54.68 \pm 1.36 \%$ PHA of the cell dry weight when grown on cane molasses

(iv) $\quad 62.12 \pm 3.09 \% \mathrm{PHA}$ of the cell dry weight when grown on hydrolysed commercial pectin

(v) $\quad 62.14 \pm 1.04 \%$ PHA of the cell dry weight when grown on hydrolysed wafer residue

In the study of Purushothaman et al.(2001), Azotobacter beijerinckii DSM 1041 was reported to 
accumulate $25 \%$ PHA of the dry cell weight when grown on a mixture of molasses and corn steep liquor (mixture $65.4 \mathrm{~g} \mathrm{~L}^{-1}$ and $13.2 \mathrm{~g} \mathrm{~L}^{-1}$ ). Wu, (2001) reported a maximum accumulation of $35-40 \%$ PHA of the dry cell weight in Bacillus $s p$. strain when grown on molasses as the carbon source. Beaulieu et al. (1995) reported an accumulation of $44 \%$ PHA of the cell dry weight in Alcaligenes eutrophus DSM 545 after $75 \mathrm{~h}$ of fermentation in medium containing $0.5 \mathrm{~g} \mathrm{~L} \mathrm{~L}^{-1}$ molasses. The highest reported accumulation so far was $76.9 \%$ PHA of the cell dry weight by Alcaligenes eutrophus DSM 545 when grown on hydrolysed potato processing waste (Rusendi and Sheppard, 1995).

Therefore, this result of $57.7 \%$ PHB of the cell dry weight achieved in Pseudomonas aeruginosa when grown on cheap and renewable reducing sugar hydrolysate obtained from cassava starch has qualified this microorganism as a potential candidate for commercial polyhydroxybutyrate production.

\section{CONCLUSION}

Pseudomonas aeruginosa was found to utilize natural, cheap and renewable reducing sugar hydrolysate from cassava starch as substrate for polyhydroxybutyrate production in batch fermentation processes. This ability is an advantage because commercial production of value added products such as polyhydroxybutyrate from cassava starch will not only ensure reduction in manufacturing costs, but will also go a long way to solve the problem associated with management of synthetic polymer wastes.

\section{REFERENCES}

Anderson, A.J. and Dawes, E.A (1990) Occurrence, metabolism, metabolic role, and industrial uses of bacterial polyhydroxyalkanoates. Microbiol. Rev. 54: 450-472.

Aransiola, E.F., Betiku, E., Adetunji, O.A. and Solomon, B.O.(2006). Production of Baker's Yeast (Saccharomyces cerevisiae) from raw cassava Cassava Starch Hydrolysates in a Bioreactor under Batch Process. Biotechnology, 5(1), 98-103.

Beaulieu, M., Beaulieu, Y., Melinard, J., Pandian, S., and Goulet, J. (1995). Influence of ammonium salts and cane molasses on growth of Alcaligenes eutrophus and production of polyhydroxybutyrate. Applied and Environmental Microbiology, 61, 165.
Bender, D. A., and A. E. Bender. (2005). A Dictionary of Food and Nutrition. New York: Oxford University Press. ISBN 0198609612

Brandl, H., Gross, R.A., Lenz, R.W. and Fuller, R.C. (1988) Pseudomonas oleovorans as a source of poly $(\beta-$ hydroxyalkanoates) for potential applications as biodegradable polyesters. Appl. Environ. Microbiol. 54: 1977-1982.

El-Holi, M. A. and Al-Delaimy, K.S. (2003) Citric Acid Production from Whey with Sugars and Additives by Aspergillus niger. African Journal of Biotechnology, 2: 356-359.

Gaouar, O., C. Aymard, N. Zakhia and G.M. Rios (1997b) Enzymatic hydrolysis of cassava starch into maltose syrup in a continuous membrane reactor. J. Chem. Technol. Biotechnol., 69: 367 - 375 .

Gorinstein, S.(1993) Kinetic Studies during Enzyme Hydrolysis of Potato and Cassava Starch. Starch/Starke, 49, 91 - 95.

Katz, S. H., and W. W. Weaver. 2003. Encyclopedia of Food and Culture. New York: Schribner. ISBN 0684805685

Lafferty, R.M., Korstko B. and Korsatko W. (1988). Microbial production of poly (3-hydroxybutyric acid). In: Rehm H.J. and Reed G. eds. Biotechnology, Vol. 6. Verlagsgesellschaft, Weinheim, Germany. Pp. 135176.

Lee, B., Pometto III, A. L., Fratzke, A., Bailey,T. B.(1991) Biodegradation of degradable plastic polythene by Phanerochaete and Streptomyces species. Appl. Environ. Microbiol. Vol.57: Pp 678-685.

Lee, S.Y. (1996) Bacterial Polyhydroxyalkanoates, A review. Biotechnol. Bioeng., (49):1 - 14.

Madison, L. and Huisman, G. W. (1999) Metabolic engineering of poly(3-hydroxyalkanoates): From DNA to plastic. Microbiology and Molecular Biology Reviews, 63, 21.

Marchessault, P. (1996) Fermentation methods for the production of poly(3-hydroxybutyrate) by Alcaligenes eutrophus DSM 545. MSc Thesis,McGill University Canada.

M.C. Santimano, Nimali N. Prabhu and S. Garq (2009) PHA Production Using Low-Cost Agro-Industrial Wastes by Bacillus sp. Strain COL1/A6. J. Microbiology, 4(3): 89 - 96.

Miller, G.L (1959) Use of dinitrosalicyclic acid reagent for determination of reducing sugar, Analytical Chemistry, Washington, D.C, 31: $426-428$. 
Am. J. Sci. Ind. Res., 2010, 1(3): 421-426

Omemu, A.M., I. Akpan, M.O. Bankole and O.D. Teniola (2005) Hydrolysis of raw tuber starches by amylase of Aspergillus niger AM07 isolated from the soil. Afr. J. Biotechnol., 4: 19 - 25.

Page, W.J. (1992). Suitability of comercial beet molasses fractions as substrates for polyhidroxyalkanoate production by Azotobacter vinelandii UWD.Biotechnology Letters 14:385-390.

Poirier, Y., Nawrath, C. and Somerville, C. (1995) Production of Polyhydroxylalkanoates; a family of
Biodegradable plastics and Elastomers in Bacteria and plants: A review. BioTechnology (13): 142-150.

Riis, V. and Mai, I. (1988) Gas chromatographic determination of poly- $\beta$-hydroxybutyric acid in microbial biomass after hydrochloric acid propanolysis. J. Chromatography, 445: 285-9

Rusendi, D. and Sheppard, J.D. (1996) Hydrolysis of potato processing waste for the production of poly- $\beta$ hydroxybutyrate. Elsevier J. of Bioresource Technology 54: 191-196. 